\title{
Penerapan model pembelajaran kooperatif tipe TGT (Teams Games Tournament) pada materi sistem persamaan linear dua variabel (SPLDV) untuk meningkatkan hasil belajar matematika siswa kelas 8-G SMP Negeri 19 Malang
}

\author{
Ratna Prabawati, I Made Sulandra*, Lathiful Anwar \\ Universitas Negeri Malang, Jl. Semarang No. 5 Malang, Jawa Timur, Indonesia \\ *Penulis korespondensi, Surel: made.sulandra.fmipa@um.ac.id
}

Paper received: 01-11-2021; revised: 15-11-2021; accepted: 30-11-2021

\begin{abstract}
Abstrak
Hasil belajar matematika siswa kelas 8-G SMPN 19 Malang masih tergolong rendah, selain itu metode pembelajaran yang dilaksanakan berpusat pada guru, pembentukan kelompok belajar tidak pernah dilakukan, sehingga kerja sama antar siswa kurang terlihat, dan guru belum pernah menerapkan TGT. Oleh karena itu, dalam PTK ini diterapkan pembelajaran kooperatif tipe TGT yang dapat meningkatkan hasil belajar matematika siswa. Data hasil belajar siswa diperoleh dari rata-rata skor kelompok, dinamika kelompok, turnamen, dan tes akhir. Berdasarkan data hasil belajar, dapat disimpulkan bahwa penerapan pembelajaran kooperatif tipe TGT meningkatkan hasil belajar matematika siswa kelas 8-G SMPN 19 Malang. Proses pembelajaran ini diawali dengan mengecek kemampuan prasyarat dan menyampaikan materi secara ringkas dengan tanya jawab, guru mengkoordinasikan siswa untuk belajar kelompok, diadakan turnamen, penghargaan kelompok, evaluasi dan refleksi. PTK ini berlangsung selama 2 siklus, dengan peningkatan hasil belajar 54,76 persen, yaitu 33,34 persen (siklus I) dan 21,42 persen (siklus II).
\end{abstract}

Kata kunci: Teams Games Tournament; hasil belajar; pembelajaran kooperatif.

\section{Pendahuluan}

Matematika yang diajarkan di tingkat pendidikan dasar dan pendidikan menengah adalah matematika sekolah (Suherman, 2003: 55). Menurut Permendiknas No 22 Tahun 2006 (Depdiknas, 2006: 346) salah satu tujuan matematika pada pendidikan menengah adalah agar peserta didik memiliki kemampuan memahami konsep matematika, menjelaskan keterkaitan antar konsep dan mengaplikasikan konsep atau logaritma, secara luwes, akurat, efisien, dan tepat dalam pemecahan masalah. Kesulitan pada matematika salah satunya disebabkan karena pembelajaran matematika bersifat monoton yaitu siswa hanya mendengarkan penjelasan dari guru kemudian diberi latihan soal sebanyak mungkin, siswa masih pasif terlibat dalam kegiatan pembelajaran, sehingga pemahaman siswa tentang konsep matematika rendah. Padahal pada umumnya siswa telah mengenal ide-ide matematika sejak dini. Salah satu dampak yang dihasilkan dari pembelajaran yang bersifat monoton ini yaitu rendahnya hasil belajar matematika siswa.

Metode pembelajaran matematika yang dilakukan di kelas 8-G SMPN 19 Malang masih berpusat pada guru (teacher centered), yaitu (1) guru menjelaskan materi, (2) guru memberikan contoh soal, (3) siswa diminta mengerjakan latihan soal, (4) memberikan pekerjaan rumah (PR), sehingga mengakibatkan siswa kurang antusias mengikuti pelajaran. Siswa menjadi pasif, enggan, takut, dan malu untuk bertanya. Mereka memilih untuk diam jika ada hal yang belum mereka pahami daripada harus bertanya kepada guru. Selain itu, keaktifan siswa untuk mengerjakan pekerjaan rumah (PR) masih kurang, alasan siswa tidak mengerjakan PR kebanyakan karena tidak bisa mengerjakan, malas, lupa, dan lain 
sebagainya. Informasi tentang pembelajaran di kelas dengan pembentukan kelompok belajar juga masih jarang bahkan hampir tidak pernah dilakukan, sehingga kerja sama antar siswa juga kurang terlihat. Pembelajaran yang monoton berpusat pada guru, mengakibatkan hasil belajar siswa SMP Negeri 19 Malang kurang maksimal.

Dari penelitian-penelitian tentang pembelajaran kooperatif tipe TGT (Teams Games Tournament) yang telah dilakukan menunjukkan hasil yang positif, yaitu hasil belajar maupun keaktifan siswa meningkat. Penelitian tersebut antara lain: penelitian Tutuk (2012) mengenai pembelajaran dengan model TGT (Teams Games Tournament) dengan jenis penelitian tindakan kelas (PTK). Dalam penelitiannya Tutuk menyimpulkan bahwa penerapan model pembelajaran TGT dapat meningkatkan prestasi belajar siswa kelas X B1 SMA Negeri 2 Malang. Penelitian Dwi (2011) mengenai penerapan pembelajaran kooperatif tipe TGT dengan jenis penelitian tindakan kelas (PTK). Dalam penelitiannya Dwi menyimpulkan bahwa dari pelaksanaan penelitian di kelas X-5 SMA Negeri 9 Malang, pembelajaran kooperatif tipe TGT dapat meningkatkan hasil belajar siswa.

Di kelas 8-G SMPN 19 Malang belum pernah diterapkan pembelajaran kooperatif tipe TGT dan mengingat keberhasilan TGT pada penelitian-penelitian sebelumnya, maka perlu dilakukan PTK dengan menerapkan model pembelajaran kooperatif tipe TGT pada materi SPLDV untuk meningkatkan hasil belajar matematika siswa kelas 8-G SMPN 19 Malang.

\section{Metode}

Penelitian ini dilakukan dengan menggunakan pendekatan penelitian kualitatif yang artinya bahwa penelitian ini berusaha memperoleh informasi dari keadaan yang sedang berlangsung pada saat penelitian dilaksanakan. Penelitian ini ditempuh untuk mengetahui peningkatan hasil belajar matematika siswa setelah diterapkan pembelajaran kooperatif tipe TGT. Pada penelitian ini, peneliti bertindak sebagai perencana tindakan, pelaksana tindakan, pengumpul data, penganalisis data, dan pelapor hasil penelitian. Dalam kegiatan pengamatan dan pengumpul data, peneliti dibantu oleh dua rekan sejawat. Penelitian dilakukan di SMP Negeri 19 Malang Jalan Belitung No. 1 Malang. Penelitian ini dilaksanakan pada semester ganjil tahun ajaran 2013/2014. Subjek pada penelitian ini adalah siswa-siswi kelas 8-G yang terdiri dari 42 siswa, dengan komposisi siswa perempuan 20 orang dan siswa laki-laki 22 orang.

Data yang diambil antara lain, (1) skor siswa, yaitu hasil skor dinamika kelompok siswa dan diskusi kelompok yang diperoleh siswa selama kegiatan belajar kelompok. Hasil skor kelompok siswa setelah kegiatan turnamen untuk penentuan penghargaan kelompok dan skor tes akhir setiap tindakan yang diperoleh siswa dalam mengerjakan soal-soal yang diberikan oleh peneliti, (2) hasil observasi untuk keterlaksanaan RPP berupa skor berdasarkan lembar observasi yang telah dirancang oleh peneliti, (3) catatan lapangan, memuat catatan objektif mengenai kegiatan penelitian dan kegiatan siswa selama pembelajaran yang berkaitan dengan tindakan yang dilakukan, dan (4) hasil wawancara, diperoleh dari wawancara antara peneliti dengan siswa yang disajikan subjek penelitian. Sumber data dalam penelitian ini diantaranya, (a) siswa sebagai sumber data tentang aktivitas belajar siswa selama pembelajaran dan hasil belajar siswa dan (b) peneliti sebagai guru untuk melihat tingkat keberhasilan penerapan model pembelajaran kooperatif tipe TGT dan aktivitas belajar serta hasil belajar siswa dalam pembelajaran. 
Beberapa teknik pengumpulan data dalam penelitian ini, antara lain (1) tes, ada saat penelitian terdapat 2 macam tes, yaitu tes pada turnamen dan tes akhir siklus, turnamen dilaksanakan pada setiap pembelajaran, tes akhir tindakan yang digunakan dalam penelitian ini adalah tes yang dilakukan pada setiap akhir siklus untuk memperoleh data peningkatan hasil belajar siswa, soal tes yang digunakan dalam bentuk tertulis, (2) observasi, dilakukan untuk mengamati keterlaksanaan RPP selama proses pembelajaran dengan penerapan pembelajaran kooperatif tipe TGT, (3) catatan lapangan, dilakukan untuk mengamati aktivitas yang terjadi selama pembelajaran berlangsung yang belum ada pada dalam lembar observasi, dan (4) Wawancara, dilakukan untuk mendapatkan keterangan untuk tujuan penelitian dengan cara tanya jawab antara peneliti dengan subjek dengan memakai panduan wawancara.

Teknik analisis data yang digunakan adalah teknik analisis data kualitatif yaitu (1) reduksi data, dilakukan untuk penyederhanaan dan abstraksi terhadap data yang terkumpul, meliputi hasil wawancara, hasil observasi, dan catatan lapangan, (2) penyajian data, data yang telah direduksi kemudian dideskripsikan secara naratif sehingga dapat dilihat gambaran keseluruhan dalam bentuk paparan data yang diperoleh selama pembelajaran. (3) pemberian kesimpulan, dan verifikasi data, pada tahap ini dilakukan kegiatan yang meliputi menentukan arti atau makna mengenai data yang diperoleh dan memberikan penjelasan, selanjutnya menguji kebenaran dengan verifikasi.

\section{Hasil dan Pembahasan}

\subsection{Hasil}

Pembelajaran dilakukan dalam dua siklus. Masing-masing siklus akan dijabarkan berikut ini.

\section{Siklus I}

Pada tahap perencanaan, hal yang dilakukan peneliti antara lain menyusun RPP, mempersiapkan LKK, mempersiapkan kartu-kartu bernomor yang berisi soal-soal turnamen beserta kunci jawabannya, mempersiapkan soal tes 1 beserta rubrik penskorannya, mempersiapkan lembar observasi keterlaksanaan RPP, catatan lapangan, dan wawancara, membagi siswa ke dalam 7 kelompok belajar, membagi siswa ke dalam 6 meja turnamen secara homogen, mengkoordinasi para observer, dan merancang lembar validasi.

Siklus I dilaksanakan dalam 3 pertemuan. Pertemuan pertama difokuskan pada materi menyelesaikan SPLDV dengan metode grafik, pertemuan kedua difokuskan pada materi menyelesaikan SPLDV dengan metode eliminasi, substitusi, dan gabungan, pertemuan ketiga difokuskan pada tes akhir siklus I.

Pertemuan Pertama dilaksanakan dalam $2 \times 40$ menit. Langkah kegiatan yang dilakukan siswa akan diuraikan sebagai berikut.

\section{Kegiatan Pendahuluan}

Pada tahap ini, kegiatan yang dilakukan adalah penyajian kelas (mengajar). Seperti yang terurai pada Kahfi (2011), tahap mengajar pada pembelajaran kooperatif tipe TGT mencakup kegiatan pembukaan, pengembangan, dan praktik terbimbing. Pada kegiatan pembukaan guru menyampaikan tujuan pembelajaran antara lain (1) Siswa dapat 
menentukan selesaian dari SPLDVdan (2) Siswa dapat menyelesaikan SPLDV dengan menggunakan metode grafik. Kemudian guru memberikan motivasi berupa penyampaian kegunaan materi. Setelah itu guru memberikan apersepsi dengan mengkaji secara singkat informasi prasyarat seperti persamaan garis lurus dan grafik. Peneliti meminta siswa memberikan salah satu contoh dari persamaan garis lurus, kemudian peneliti meminta siswa untuk menggambarkan grafik dari persamaan garis lurus yang telah disebutkan. Dari grafik yang digambar di depan ada siswa yang kurang paham bagaimana cara menggambar grafik tersebut, kemudian peneliti menjelaskan langkah-langkah menggambarkan grafik suatu persamaan garis lurus.

\section{Kegiatan Inti}

Kegiatan inti diawali dengan kegiatan penyajian kelas tahap pengembangan, peneliti meminta siswa untuk menyebutkan contoh lain dari persamaan garis lurus. Peneliti meminta siswa untuk menggambarkan persamaan garis lurus yang telah disebutkan pada bidang koordinat Cartesius yang sudah dibuat oleh siswa yang pertama tadi. Dari gambar yang dibuat,peneliti mencoba menjelaskan bahwa dua persamaan garis lurus tersebut merupakan salah satu contoh dari SPLDV. Dari kedua grafik tersebut diperoleh bahwa kedua persamaan garis lurus itu berpotongan di satu titik. Dan titik potong yang terbentuk dari kedua persamaan merupakan penyelesaian dari SPLDV. Pada kegiatan praktik terbimbing, peneliti meminta siswa mengerjakan contoh soal yang diberikan oleh peneliti. Kemudian memanggil siswa secara acak untuk menyampaikan jawabannya.

Kegiatan selanjutnya adalah kegiatan teams (belajar kelompok). Persiapan belajar kelompok yang dilakukan peneliti antara lain (1) meminta siswa langsung bergabung dengan kelompok, (2) membagikan LKK 1 kepada masing-masing kelompok. Siswa mempelajari LKK 1 dengan berdiskusi bersama anggota kelompoknya. Peneliti hanya sebagai fasilitator berkeliling mengamati jalannya diskusi, selain itu peneliti juga memberikan skor dinamika kelompok, dan memberikan bantuan jika diperlukan.

Selanjutnya yaitu kegiatan permainan dan turnamen. Persiapan yang dilakukan peneliti antara lain (1) meminta siswa menuju meja turnamen, (2) membagikan kartu-kartu bernomor yang berisi soal-soal turnamen beserta kunci jawabannya, (3) menjelaskan teknis turnamen. Peneliti sebagai fasilitator berkeliling untuk mengamati jalannya turnamen dan mengontrol siswa agar tidak terjadi kecurangan.

Kegiatan penskoran dilakukan oleh peneliti sendiri. Dari hasil turnamen 1 siklus I kelompok 2 mendapat predikat "Tim Super Hebat" dengan perolehan skor rata-rata kelompok 46,33. Kelompok 1 mendapat predikat "Tim Hebat" dengan perolehan skor ratarata kelompok 45,33, sedangkan untuk kelompok 7 mendapat predikat "Tim Baik" dengan perolehan skor rata-rata kelompok 42,17.

\section{Kegiatan Penutup}

Peneliti pun meminta siswa mengumpulkan hasil turnamen. Peneliti menyampaikan kepada siswa mengenai kegiatan yang akan dilakukan pada pertemuan selanjutnya serta siswa diminta untuk mempersiapkan diri. Selain itu peneliti juga menyampaikan akan memberi penghargaan bagi kelompok yang terbaik. 
Pertemuan Kedua dilaksanakan dalam $3 \times 40$ menit. Langkah kegiatan yang dilakukan siswa akan diuraikan sebagai berikut.

\section{Kegiatan Pendahuluan}

Pada tahap ini kegiatan yang dilakukan adalah penyajian kelas (mengajar). Pada kegiatan pembukaan guru menyampaikan tujuan pembelajaran yaitu siswa dapat menentukan selesaian dari SPLDV dengan menggunakan metode eliminasi, substitusi, dan gabungan. Kemudian guru memberikan motivasi berupa penyampaian kegunaan materi. Setelah itu guru memberikan apersepsi dengan mengkaji secara singkat informasi prasyarat seperti metode substitusi dan eliminasi.

\section{Kegiatan Inti}

Kegiatan inti diawali dengan kegiatan penyajian kelas tahap pengembangan dan praktik terbimbing, peneliti meminta siswa untuk mengerjakan SPLDV dengan metode substitusi dan eliminasi. Peneliti meminta siswa untuk memberikan contoh dari SPLDV, kemudian peneliti mengajak siswa untuk mencari penyelesaian dari SPLDV tersebut dengan menggunakan metode substitusi dan eliminasi. Peneliti meminta perwakilan dari siswa yang dapat mengerjakannya di depan kelas. Dari hasil kerja siswa di depan kelas peneliti mencoba menjelaskan tahap-tahap dalam menyelesaikan SPLDV dengan menggunakan metode substitusi dan eliminasi.

Kegiatan selanjutnya adalah kegiatan teams (belajar kelompok). Persiapan belajar kelompok yang dilakukan peneliti antara lain (1) meminta siswa langsung bergabung dengan kelompok seperti pada pertemuan pertama, (2) membagikan LKK 2. Peneliti hanya sebagai fasilitator berkeliling mengamati jalannya diskusi, selain itu peneliti juga memberikan skor dinamika kelompok, dan memberikan bantuan jika diperlukan.

Selanjutnya yaitu kegiatan permainan dan turnamen. Persiapan yang dilakukan peneliti antara lain (1) meminta siswa menuju meja turnamen, (2) membagikan kartu-kartu bernomor yang berisi soal-soal turnamen beserta kunci jawabannya, (3) menjelaskan teknis turnamen. Kegiatan penskoran dilakukan oleh siswa kemudian diteruskan oleh peneliti sendiri. Dari hasil turnamen 2 siklus I kelompok 5 mendapat predikat "Tim Super Hebat" dengan perolehan skor rata-rata kelompok 95,17. Kelompok 3 mendapat predikat "Tim Hebat" dengan perolehan skor rata-rata kelompok 93,17, sedangkan untuk kelompok 7 mendapat predikat “Tim Baik" dengan perolehan skor rata-rata kelompok 92.

\section{Kegiatan Penutup}

Peneliti pun meminta siswa mengumpulkan hasil turnamen. Peneliti menyampaikan kepada siswa bahwa pertemuan selanjutnya akan dilakukan tes mengenai menyelesaikan SPLDV. Selain itu peneliti juga menyampaikan akan memberi penghargaan bagi kelompok yang terbaik dan memberikan hadiah bagi siswa yang mendapat skor tertinggi pada tiap turnamen.

Pertemuan ketiga dilaksanakan dalam $2 \times 40$ menit. Pada pertemuan ini diadakan tes dan pemberian penghargaan kelompok. Soal tes berupa uraian yang terdiri dari 5 soal. Setelah kegiatan tes, peneliti mengumumkan hasil turnamen dan memberi penghargaan. Penghargaan diberikan kepada tiga kelompok dengan masing-masing predikat Tim Super 
Hebat, Tim Hebat, dan Tim Baik. Selain itu peneliti juga memberikan hadiah untuk siswa yang meraih skor tertinggi pada kegiatan turnamen 1 dan 2. Pada turnamen 1 hadiah diberikan kepada MA dan pada turnamen 2 hadiah diberikan kepada SH.

Berdasarkan hasil pengamatan/observasi diperoleh kesimpulan berikut.

1. Hasil observasi keterlaksanaan RPP $84 \%$

2. Hasil ketuntasan belajar siswa, sebanyak $64,29 \%$ dari seluruh jumlah siswa telah memiliki nilai di atas SKM sekolah.

3. Hasil catatan lapangan dari observer memperlihatkan bahwa pengendalian kelas oleh peneliti masih kurang maksimal.

4. Hasil wawancara dengan salah satu siswa yaitu siswa cukup senang namun masih agak sulit menyesuaikan dengan pembelajaran yang dilakukan karena masih pengalaman pertama.

Dari refleksi yang dilakukan, meskipun hasil belajar matematika siswa mengalami peningkatan, akan tetapi masih belum memenuhi kriteria ketuntasan secara klasikal dan masih terdapat beberapa kendala selama proses pembelajaran berlangsung, maka perlu dilakukan siklus II.

\section{Siklus II}

Pada tahap perencanaan, hal yang dilakukan peneliti antara lain mempersiapkan RPP siklus II, mempersiapkan LKK, mempersiapkan instrumen penelitian berupa soal turnamen siklus II, kunci jawaban soal turnamen siklus II, soal tes akhir siklus II, kunci jawaban soal tes akhir siklus II, lembar observasi keterlaksanaan RPP siklus II, lembar wawancara, dan format catatan lapangan.

Siklus I dilaksanakan dalam 2 pertemuan. Pertemuan pertama difokuskan pada materi menentukan penyelesaian dari masalah yang berkaitan dengan SPLDV dan penafsirannya dengan metode grafik, eliminasi, substitusi, dan gabungan, pertemuan kedua difokuskan pada tes akhir siklus II.

Pertemuan Pertama dilaksanakan dalam $3 \times 40$ menit. Langkah kegiatan yang dilakukan siswa akan diuraikan sebagai berikut

Kegiatan Pendahuluan

Pada tahap ini kegiatan yang dilakukan adalah penyajian kelas (mengajar). Pada kegiatan pembukaan guru menyampaikan tujuan pembelajaran. Kemudian guru memberikan motivasi berupa penyampaian kegunaan materi yaitu menghubungkan materi SPLDV dengan masalah sehari-hari, misalnya menentukan harga satuan barang dan menentukan panjang atau lebar sebidang tanah. Setelah itu guru memberikan apersepsi dengan mengkaji secara singkat informasi prasyarat seperti menyusun model matematika dari permasalahan dalam kehidupan sehari-hari yang berhubungan dengan SPLDV. Peneliti melakukan tanya jawab kepada siswa mengenai menyusun kalimat matematika (model matematika) dari soal cerita sehingga menjadi sistem persamaan linear dua variabel. 


\section{Kegiatan Inti}

Kegiatan inti diawali dengan penyajian kelas tahap pengembangan dan praktik terbimbing, peneliti meminta siswa untuk menyelesaikan contoh suatu masalah dalam kehidupan sehari-hari yang berhubungan dengan SPLDV. Kemudian peneliti memanggil nama siswa secara acak untuk mengerjakannya di depan.

Kegiatan selanjutnya adalah kegiatan teams (belajar kelompok). Setelah siswa berkumpul dengan kelompoknya masing-masing, peneliti membagikan LKK kepada masingmasing kelompok. Siswa mempelajari LKK dengan berdiskusi bersama anggota kelompoknya. Peneliti hanya sebagai fasilitator berkeliling mengamati jalannya diskusi, selain itu peneliti juga memberikan skor dinamika kelompok, dan memberikan bantuan jika diperlukan.

Selanjutnya yaitu kegiatan permainan dan turnamen. Persiapan yang dilakukan peneliti antara lain (1) meminta siswa menuju meja turnamen dengan susunan peserta yang telah ditentukan, (2) membagikan kartu-kartu bernomor yang berisi soal-soal turnamen beserta kunci jawabannya, (3) menjelaskan teknis turnamen. Peneliti sebagai fasilitator berkeliling untuk mengamati jalannya turnamen dan mengontrol siswa agar tidak terjadi kecurangan.

Peneliti meminta siswa untuk mengumpulkan hasil kerja mereka pada saat kegiatan turnamen. Kegiatan penskoran dilakukan oleh peneliti sendiri. Dari hasil turnamen siklus II kelompok 1 mendapat predikat "Tim Super Hebat" dengan perolehan skor rata-rata kelompok 73,83. Kelompok 2 mendapat predikat "Tim Hebat" dengan perolehan skor ratarata kelompok 72,83, sedangkan untuk kelompok 5 mendapat predikat "Tim Baik" dengan perolehan skor rata-rata kelompok 72,17.

\section{Kegiatan Penutup}

Peneliti menutup kegiatan pembelajaran. Peneliti tidak lupa menyampaikan kepada siswa bahwa pertemuan selanjutnya akan dilakukan tes mengenai menentukan penyelesaian dari masalah yang berkaitan dengan SPLDV dan penafsirannya dengan metode grafik, eliminasi, substitusi, dan gabungan. Selain itu peneliti juga menyampaikan akan memberi penghargaan bagi kelompok yang terbaik dan memberikan hadiah bagi siswa yang mendapat skor tertinggi pada tiap turnamen.

Pertemuan kedua dilaksanakan dalam $2 \times 40$ menit. Pada pertemuan ini diadakan tes dan pemberian penghargaan kelompok. Soal tes berupa uraian yang terdiri dari 4 soal. Setelah kegiatan tes, peneliti mengumumkan hasil turnamen dan memberi penghargaan. Penghargaan diberikan kepada tiga kelompok dengan masing-masing predikat Tim Super Hebat, Tim Hebat, dan Tim Baik. Selain itu peneliti juga memberikan hadiah untuk siswa yang meraih skor tertinggi pada kegiatan turnamen. Pada turnamen hadiah diberikan kepada MA dan AS. 
Berdasarkan hasil pengamatan/observasi diperoleh kesimpulan berikut.

\section{Hasil observasi keterlaksanaan RPP $86,5 \%$}

2. Hasil ketuntasan belajar siswa, sebanyak $85,71 \%$ dari seluruh jumlah siswa telah memiliki nilai di atas SKM sekolah.

3. Hasil catatan lapangan dari observer memperlihatkan bahwa respon siswa dalam pelaksanaan setiap kegiatan dalam pembelajaran menunjukkan respon yang lebih positif.

4. Hasil wawancara dengan salah satu siswa yaitu siswa menyukai pembelajaran matematika melalui pembelajaran kooperatif tipe TGT karena siswa merasa senang belajar berkelompok dan turnamen.

Dari refleksi yang dilakukan, mendapatkan kesimpulan bahwa hasil belajar matematika siswa mengalami pengingkatan dan sudah mencapai kriteria ketuntasan minimum secara klasikal, shingga penelitian dapat dihentikan pada siklus II karena data penelitian yang diperoleh telah mencapai target penelitian.

\subsection{Pembahasan}

Pembelajaran kooperatif pada penelitian ini dilaksanakan sesuai dengan tahap-tahap pada pembelajaran kooperatif tipe TGT. Berdasarkan Kahfi (2011: 8) tahap-tahap pembelajaran kooperatif tipe TGT meliputi: (a) mengajar (penyajian kelas), menurut Kahfi (2011: 9), pembelajaran dengan model TGT dimulai dengan penyajian ke seluruh kelas yang mencakup kegiatan pembukaan, pengembangan, dan praktik terbimbing, pada tahap pembukaan, guru memberi tahu siswa apa yang akan mereka pelajari, tujuan pembelajaran, memberikan motivasi, dan mengkaji secara singkat materi prasyarat, pada tahap pengembangan, guru fokus ke tujuan yang ingin dicapai dan sering menilai kemajuan siswa dengan mengajukan banyak pertanyaan, dan pada tahap praktik terbimbing, guru meminta siswa untuk mengerjakan soal atau contoh, memanggil siswa secara acak untuk mengerjakan hasil kerjanya di depan kelas, (b) belajar kelompok, peneliti dalam tahap ini membagi siswa dalam 7 kelompok belajar yang heterogen terdiri dari 6 anggota, kemudian peneliti membagikan LKK, seperti pada Slavin (2005) dalam tahap belajar kelompok setiap siswa dalam kelompok mempelajari dan menguasai materi melalui pengerjaan LKK atau bahan ajar lainnya, peneliti hanya sebagai fasilitator untuk memberikan bantuan seperlunya seperti yang tertuang dalam Dimyati dan Mudjiono (1999:16) bahwa beberapa saran pembelajaran untuk guru agar siswa belajar optimal salah satunya adalah guru bertindak sebagai fasilitator, (c) turnamen merupakan ciri khas dari pembelajaran kooperatif tipe TGT, pada tahap ini, siswa dibagi ke dalam 6 meja turnamen yang terdiri dari 7 siswa dengan kemampuan homogen dan setiap meja turnamen merupakan perwakilan dari kelompok belajar, hal ini sesuai dengan yang diungkapkan Slavin (2005) bahwa dalam turnamen, siswa yang berkemampuan setara dari kelompok yang berbeda menempati meja yang sama untuk bertanding, pada setiap meja turnamen siswa berkompetisi untuk menjawab soal pada kartu bernomor dan skor yang diperoleh akan dijumlahkan dengan skor yang diperoleh oleh anggota lain sehingga diperoleh skor untuk kelompok belajar, kemudian dihitung skor ratarata kelompok dengan membagi jumlah skor kelompok dengan jumlah anggota kelompok, skor rata-rata yang diperoleh ini sebagai penentu penghargaan kelompok, dan (d) 
penghargaan kelompok, perolehan skor rata-rata kelompok pada kegiatan turnamen digunakan sebagai penentu penghargaan kelompok. Selain itu, peneliti juga memberikan hadiah untuk siswa yang memperoleh skor tertinggi pada saat kegiatan turnamen. Sesuai dengan Slavin (2005), penghargaan yang diberikan berupa sertifikat atau bentuk-bentuk lainnya.

Pembelajaran kooperatif tipe TGT dapat meningkatkan hasil belajar. Berdasarkan data hasil penelitian, diketahui hasil belajar matematika siswa kelas 8-G SMP Negeri 19 Malang meningkat setelah dilakukan pembelajaran dengan pembelajaran kooperatif tipe TGT. Hasil belajar siswa siklus I menunjukkan adanya peningkatan setelah mengikuti pembelajaran matematika dengan pembelajaran kooperatif tipe TGT yaitu 64,29\% siswa mendapatkan nilai minimal 75. Padahal sebelum diberikan tindakan siswa yang mendapat nilai minimal 75 adalah 30,95\%, sehingga terjadi peningkatan sebesar 33,34\%. Meskipun telah mengalami peningkatan hasil belajar maupun persentase ketuntasan belajar secara klasikal, akan tetapi belum dapat dikatakan tuntas karena persentase ketuntasan belajar secara klasikal minimal harus mencapai 75\%. Oleh karena itu, dilanjutkan siklus II. Hasil belajar siklus II yaitu $85,71 \%$ siswa mendapat nilai minimal 75 . Hasil ini jika dibandingkan dengan siklus I mengalami peningkatan. Dapat disimpulkan bahwa ada peningkatan hasil belajar dengan adanya pembelajaran matematika dengan pembelajaran kooperatif tipe TGT. Hal ini sesuai dengan hasil penelitian oleh Tutuk (2012) yang menyimpulkan bahwa penerapan model pembelajaran TGT dapat meningkatkan prestasi belajar siswa kelas X B1 SMA Negeri 2 Malang dan penelitian oleh Dwi (2011) yang menyimpulkan bahwa dari pelaksanaan penelitian di kelas X-5 SMA Negeri 9 Malang, pembelajaran kooperatif tipe TGT dapat meningkatkan hasil belajar siswa. Berdasarkan hasil yang telah dicapai selama pelaksanaan pembelajaran matematika dengan menerapkan pembelajaran kooperatif tipe TGT siswa mengalami peningkatan hasil belajar pada setiap siklus. Hal ini didukung pernyataan dari Johnson dalam Lia (2005: 7), suasana belajar cooperative learning menghasilkan prestasi yang lebih tinggi, hubungan yang lebih positif, dan penyesuaian psikologis yang lebih baik.

\section{Simpulan}

\subsection{Kesimpulan}

Dari pelaksanaan penelitian di kelas 8-G SMP Negeri 19 Malang dan berdasarkan keterlaksanaan pembelajaran kooperatif tipe TGT yang telah dideskripsikan, maka dapat disimpulkan bahwa pembelajaran kooperatif tipe TGT dapat meningkatkan hasil belajar matematika siswa. Pembelajaran kooperatif tipe TGT dapat meningkatkan hasil belajar matematika siswa melalui langkah-langkah sebagai berikut, antara lain (a) Mengajar (Penyajian Kelas), tahap penyajian kelas dalam penelitian ini mencakup kegiatan pembukaan dengan menyampaikan tujuan pembelajaran, memotivasi siswa dengan memberi contoh kegunaan materi SPLDV kemudian apersepsi dengan menyampaikan materi prasyarat melalui tanya jawab, tahap pengembangan peneliti mengarahkan siswa dari materi prasyarat yang sudah dipenuhi oleh siswa menuju ke materi yang akan dipelajari, dan praktik terbimbing dilakukan dengan cara memberikan soal atau meminta siswa untuk membuat soal kemudian memanggil siswa secara acak untuk menyampaikan hasil kerjanya, (b) Belajar Kelompok, peneliti membagi siswa menjadi 7 kelompok heterogen terdiri dari 6 anggota, dibagikan LKK berisi permasalahan tentang menentukan penyelesaian dari SPLDV untuk dikerjakan bersama kelompok belajarnya, siswa saling berdiskusi dengan teman satu kelompoknya, peneliti hanya sebagai fasilitator untuk memberikan pengarahan dan bantuan 
seperlunya, (c) Turnamen merupakan ciri khas dari pembelajaran kooperatif tipe TGT, pada tahap ini terbentuk 6 meja turnamen, siswa dibagi ke dalam meja-meja turnamen yang terdiri dari 7 siswa yang berkemampuan homogen dan anggota setiap meja turnamen merupakan perwakilan dari kelompok belajarnya, pada setiap meja turnamen, siswa bertanding untuk menjawab soal pada kartu bernomor dan skor yang diperoleh akan dijumlahkan dengan skor yang diperoleh oleh anggota kelompok belajarnya yang lain sehingga diperoleh skor untuk kelompok asal, kemudian dihitung skor rata-rata kelompok dengan membagi jumlah skor kelompok dengan banyaknya anggota kelompok, skor rata-rata kelompok ini digunakan dalam penghargaan kelompok, dan (d) Penghargaan Kelompok, penghargaan diberikan kepada kelompok berdasarkan hasil turnamen. Selain itu, peneliti juga memberikan penghargaan khusus (hadiah) untuk siswa dengan perolehan skor tertinggi di meja turnamen.

Hasil penelitian yang diperoleh dari penerapan pembelajaran kooperatif tipe TGT selama 5 pertemuan adalah meningkatnya hasil belajar matematika siswa kelas 8-G SMP Negeri 19 Malang yang terlihat pada nilai akhir yang merupakan rata-rata dari skor kelompok, skor dinamika kelompok, skor turnamen, dan skor tes akhir pada setiap siklus. Hasil akhir pada siklus I memperoleh persentase ketuntasan belajar secara klasikal sebesar 64,29\%, sedangkan hasil akhir pada siklus II memperoleh persentase ketuntasan belajar secara klasikal sebesar $85,71 \%$. Serta keterlaksanaan RPP selama pembelajaran kooperatif tipe TGT masuk dalam kategori "Sangat Baik" pada siklus I dan siklus II.

\subsection{Saran}

Penerapan pembelajaran kooperatif tipe TGT juga dapat dikembangkan untuk mata pelajaran yang lain, sebaiknya dilakukan variasi pembelajaran agar siswa tidak bosan. Misalnya dengan variasi teknis turnamen yang lebih kreatif, selain itu juga bisa memanfaatkan media komputer pada pelaksanaannya. Penelitian ini hanya terbatas pada materi SPLDV sehingga peneliti menyarankan agar dikembangkan untuk materi yang lain. Pembelajaran kooperatif tipe TGT ini memiliki beberapa kelemahan antara lain membutuhkan waktu yang banyak, membutuhkan seperangkat kartu bernomor untuk turnamen, siswa terbiasa belajar karena ada hadiah. Meskipun memiliki kelemahan membutuhkan banyak waktu namun pembelajaran kooperatif tipe TGT dapat diterapkan guru sebagai inovasi dengan cara menerapkannya 2-3 kali dalam satu semester. Tahap turnamen dalam pembelajaran kooperatif tipe TGT dapat digunakan sebagai pengganti kuis yang biasanya diadakan oleh guru sebagai latihan soal menjelang ulangan. Dengan artian kegiatan turnamen merupakan kuis dengan kemasan yang berbeda.

\section{Daftar Rujukan}

Departemen Pendidikan Nasional. (2006). Peraturan menteri pendidikan nasional Nomor 22 Tahun 2006 tentang standar isi untuk satuan pendidikan dasar dan menengah. Jakarta: Depdiknas.

Dimyati dan Mudjiono. (1999). Belajar dan pembelajaran. Jakarta: Rineka Cipta.

Kahfi, Muhammad Shohibul. (2011). Mengembangkan skenario pembelajaran matematika berbasis kompetensi (contoh-contoh model). Malang: Universitas Negeri Malang.

Lia, Anita. 2005. Mempraktikkan cooperative learning di ruang-ruang kelas. Jakarta: Grasindo.

Rahayu, Tutuk Dwi. (2012). Penerapan model pembelajaran TGT (Teams Games Tournament) untuk meningkatkan prestasi belajar matematika siswa kelas X BI SMA Negeri 2 Malang. Malang: Universitas Negeri Malang. 
Setyorini, Dwi. (2011). Penerapan pembelajaran kooperatif tipe TGT (Teams Games Tournament) untuk meningkatkan hasil belajar matematika pada siswa kelas X SMA Negeri 9 Malang. Skripsi tidak diterbitkan. Malang: Unversitas Negeri Malang.

Slavin, Robert E. (2005). Cooperative learning teori dan praktik. Bandung: Nusa Media.

Suherman, Erman. (2003). Strategi pembelajaran matematika kontemporer. Bandung: Universitas Pendidikan Indonesia. 